\title{
Sistem Informasi Reservasi Gedung Serbaguna di Kota Palembang Berbasis Android
}

\author{
Andi Ahmad Prasetia ${ }^{1}$, Freddy Kurnia Wijaya ${ }^{2}$, Evi Fadilah ${ }^{3}$ \\ andiahmadp@gmail.com ${ }^{1}$, freddykurniawijaya_uin@radenfatah.ac.id ${ }^{2}$, \\ evifadilah_uin@radenfatah.ac.id ${ }^{3}$
}

\author{
${ }^{1}$ Prodi Sistem Informasi, Fakultas Sains dan Teknologi, UIN Raden Fatah Palembang \\ ${ }^{2}$ Prodi Sistem Informasi, Fakultas Sains dan Teknologi, UIN Raden Fatah Palembang \\ ${ }^{3}$ Prodi Sistem Informasi, Fakultas Sains dan Teknologi, UIN Raden Fatah Palembang
}

Diterima: 1 Juni 2017 | Direvisi: 20 Juni 2017 | Disetujui: 18 Juli 2017

(c) 2017 Program Studi Sistem Informasi Fakultas Sains dan Teknologi, Universitas Islam Negeri Raden Fatah Palembang, Indonesia

\begin{abstract}
Abstrak: Terdapat banyak sekali gedung serbaguna yang ada di kota Palembang. Sebagai tempat untuk melaksanakan suatu acara gedung serbaguna memiliki beberapa fasilitas yang dipadu menjadi satu kesatuan untuk menyelenggarakan acara tertentu namun informasi mengenai fasilitas dan paket yang ditawarkan belum banyak tersedia sehingga penyewa bingung dalam menetapkan pilihan gedung serbaguna sehingga berdampak pada kesalahan dalam pemilihan gedung serbaguna. Sistem reservasi gedung serbaguna di kota Palembang dapat berfungsi untuk membantu penyewa untuk mendapatkan informasi jadwal gedung serbaguna yang ada dan melihat harga, fasilitas, paket, item yang ditawarkan. pada penelitian ini peneliti menggunakan metode Prototype sebagai metode pengembangan dan permodelan menggunakan UML (Unified Model Language) sedangkan pembuatan aplikasinya sendiri menggunakan bahasa pemrograman Java pada bagian android dan bahasa pemograman PHP pada bagian website dengan MySQL untuk pengolahan databasenya. Sistem informasi reservasi gedung serbaguna di kota Palembang berbasis android dapat mengumpulkan, mengidentifikasi, menyimpan, mengelola dan memberikan informasi beberapa gedung serbaguna yang ada di kota Palembang yang dijadikan sample dalam penelitian ini.
\end{abstract}

Kata Kunci: Sistem Informasi, Reservasi, Android

\begin{abstract}
There are many halls in the city of Palembang as a place to carry out an event. The hall has several facilities combined into one unity to organize certain events. However, information about the facilities and packages offered are not available so the tenants are confused in determining the choice of building so that the wrong impact in the selection of buildings. In this case Hall reservation information system in Palembang city can serve to help tenants to compare the existing versatile buildings by looking at prices, facilities, packages, and items offered. In this research, researchers use Prototype method as development and modeling method using UML (Unified Model Language). While making its own application using the Java programming language on the android and PHP programming languages on the website with MySQL for database processing. Information system of reservation hall can collect, identify, store, manage and provide information some of the existing hall in the city of Palembang as samples in this research
\end{abstract}

Keywords: Information System, Reservation, Android

\section{PENDAHULUAN}

Perkembangan teknologi komunikasi mengarah ke sebuah teknologi yang berbasis mobile atau perangkat bergerak. Saat ini mobile phone tidak hanya digunakan sebagai media komunikasi untuk telepon dan sms saja, tetapi juga sebagai media untuk berkomunikasi langsung melalui internet untuk mengirim dan menerima data. Hal ini menyebabkan 
tingginya minat terhadap sebuah smartphone, karena akan sangat menunjang bagi penggunanya dalam mengatasi kesibukan dan kebutuhan yang dimilikinya dan hampir semua orang sekarang ini membutuhkan semua hal yang bersifat cepat, praktis, efektif dan ekonomis untuk penyajian informasi. Mobile phone telah mengambil peranan yang sangat penting dalam berbagai bidang kehidupan manusia bahkan bisa jadi handphone sudah menjadi kebutuhan primer yang digunakan untuk saling berkomunikasi dan bertukar informasi. Perkembangan perangkat mobile berjalan dengan sangat cepat. Salah satu contoh yang sedang banyak dikenal dipasaran adalah mobile phone dengan menggunakan sistem operasi Android.

Berkembangnya teknologi telah mengubah pola dalam beroganisasi, dan berbisnis sehingga banyak perusahaan memanfaatkan teknologi sebagai alat untuk mempercepat kerja perusuhaan mereka. Secara tidak langsung teknologi mempengaruhi pola bisnis di indonesia. Persaingan diantara perusahaan pun sangatlah ketat dengan terus meningkatkan pelayanan terhadap para konsumenya dengan baik. Demi terwujudnya harapan yang baik, perusahaan pun terus berinovasi agar perusahaan dapat meningkatkan pelayanan terhadap konsumen.

Perkembangan bisnis di kota Palembang Sebagai salah satu kota termaju di indonesia telah banyak memanfaatkan Penggunaan teknologi yang berkembang ini untuk memudahkan usaha penyebaran informasi dan promosi bisnis mereka namun, tidak semua bisnis memanfaatkan teknologi untuk perusahaan mereka, salah satunya pada bisnis penyewaan gedung serbaguna dikota Pelembang khususnya dalam hal pelayanan mengunakan teknologi masih melakukan kebiasaan lama yaitu penyewa datang untuk memesan. Gedung-gedung serbaguna yang ada di kota Palembang sangatlah bervariasi. Mulai dari kegunaan, fasilitas, kapasitas, dan lokasi namun, banyaknya gedung serbaguna tidak diimbangi dengan tersedianya infromasi gedung, dengan memanfaatkan kemampuan dan kemudahan teknologi informasi yang berbasis mobilephone memungkinkan penyewa untuk mengakses informasi mengenai jadwal gedung yang tersedia beserta fasilitas yang ada sebagai bahan pertimbangan dalam memilih gedung sebagai tempat menyelanggarakan acara.

Acara yang diselenggarakan digedung serbaguna bermacam-macam mulai dari pernikahan, wisuda, ulang tahun, rapat, pameran, seminar, dan lain sebagainya banyak juga dari gedung-gedung tersebut menawarkan fasilitas-fasilitas yang lengkap namun tidak diimbangi dengan informasi yang lengkap. Akibat dari kurangnya informasi menyebabkan pihak penyewa salah dalam menetapkan pilihan karena tidak adanya informasi untuk melihat jadwal gedung beserta fasilitas yang ada.

\section{METODE PENELITIAN}

\subsection{Tinjauan Pustaka}

\subsubsection{Definisi Sistem}

Menurut (Fatta, 2007), sistem sebagai perangkat elemen yang digabungkan satu dengan lainnya untuk suatu tujuan yang sama. Menurut (Jogiyanto, 2005), Sistem adalah jaringan kerja dari prosedur-prosedur yang saling berhubungan, berkumpul bersama-sama untuk melakukan suatu kegiatan atau untuk menyelesaikan suatu sasaran tertentu. Sistem juga bisa diartikan sebagai kumpulan dari elemen-elemen yang berinteraksi untuk mencapai suatu tujuan tertentu. Menurut (Kristanto, 2008), sistem adalah suatu jaringan kerja dari prosedurprosedur yang saling berhubungan, berkumpul bersama-sama untuk melakukan suatu kegiatan atau menyelesaikan suatu sasaran yang tertentu.

Dari tiga pendapat maka dapat disimpulkan bahwa sistem adalah kumpulan dari elemen yang saling berhubungan untuk suatu tujuan tertentu.

\subsubsection{Karakteristik Sistem}

Suatu sistem mempunyai beberapa karakteristik, yaitu komponen atau elemen (component), batas sistem (boundary), lingkungan luar sistem (environment), penghubung (interface), masukan (input), pengolah (process), keluaran (output), sasaran (objective), atau 
tujuan (goal) (Sutabri, 2012). Karakteristik sistem mempunyai beberapa komponen diantaranya yaitu:

1. Komponen Sistem (Components) komponen-komponen sistem dapat berupa suatu subsistem atau bagian-bagian dari sistem yang saling berinteraksi, artinya saling bekerja sama membentuk satu kesatuan.

2. Batasan Sistem (boundary) merupakan daerah yang membatasi suatu sistem dengan sistem yang lainnya atau dengan lingkungan luarna. Batasan sistem ini memungkinkan suatu sistem dipandang sebagai satu kesatuan yan tidak dapat dipisah-pisahkan.

3. Lingkungan luar sistem (environment) adalah bentuk apapun diluar batas sistem yang mempengaruhu operasi sistem. Lingkungan sistem dapat bersifat merugikan atau menguntungkan sistem tersebut.

4. Penghubung (interface) melalui penghubung ini memungkinkan sumber-sumber daya mengalir dari subsistem ke subsistem yang lainnya. Dengan penghubung, stu subsistem dapat berintegrasi dengan subsistem yang lainnyamembentuk satu kesatuan.

5. Masukan sistem (input) merupakan energi yang dimasukkan kedalam sistem. Masukan dapat berupa pemeliharaan (maintenance input) dan masukan sinyal (signal input).

6. Keluaran (output) merupakan hasil dari energi yang diolah dan diklasifikasikan menjadi keluaran yang berguna. Keluaran dapaat merupakan masukan untuk subsistem yang lain.

7. Pengolah (process) suatu sistem dapat mempunyai suatu bagian pengolah yang akan mengubah masukan menjadi keluaran.

8. Sasaran (objective) suatu sistem memiliki tujuan dan sasaran yang pasti dan bersifat determinitik. Jika suatu sistem tidak memili9ki sasaran, maka operasi sistem tidak ada gunanya. Suatu sistem dikatakan berhasil bila mengenai sasaran atau tujuan yang telah direncanakan.

\subsubsection{Klasifikasi Sistem}

Ada beberapa bentuk klasifikasi sistem dilihat dari sudut pandang, diantaranya adalah (Sutabri, 2012):

a. Sistem Abstrak dan Sistem Fisik

Sistem abstrak adalah sistem yang berupa pemikiran atau ide-ide yang tidak tampak secara fisik, misalnya sistem teolegia, yaitu suatu sistem yang berupa pemikiran tentang hubungan antara manusia dengan tuhan, sedangkan sistem fisik merupakan sistem yang ada secara fisik, seperti sistem komputer, sistem produksi, sistem penjualan, dan lain sebagainya. b. Sistem Alamiah dan Sistem Buatan

Sistem alamiah adalah sistem yang terjadi melalui proses alam, tidak dibuat manusia. Sedangkan sistem buatan merupakan sistem yang melibatkan hubungan manusia dengan mesin.

c. Sistem deterministik dan sistem probobalitas

Sistem deterministik adalah sistem yang beroperasi dengan tingkah laku yang dapat diprediksi. Interaksi diantara bagian-bagiannya dapat dideteksi dengan pasti, sehingga keluaran dari sistem dapat diramalkan. Sedangkan sistem yang bersifat probobalitas adalah sistem yang kondisi masa depannya tidak dapat diprediksi karena mengandung unsur probobalitas.

d. Sistem tertutup dan sistem terbuka

Sistem tertutup merupakan sistem yang tidak berhubungan dan tidak terpengaruh dengan lingkungan luarnya. Sistem terbuka adalah sistem yang berhubungan dan terpengaruh dengan lingkungan luarnya, yang menerima masukan dan menghasilkan keluaran untuk subsistem lainnya.

\subsubsection{Definisi Data}

Sumber informasi adalah data. Data merupakan bentuk jamak dari bentuk tunggal datum atau item. Menurut McLeod dalam bukunya (Yakub, 2012) "Data adalah deskripsi kenyataan yang menggambarkan adanya suatu kejadian (event), data terdiri dari fakta (fact) 
dan angka yang secara relatif tidak berarti bagi pemakai ". Data dapat berbentuk nilai yang terformat, teks, citra, audio, dan video.

1. Teks adalah sederetan huruf, angka, dan simbol-simbol yang kombinasinya tidak tergantung pada masing-masing item secara individual misalnya, artikel koran, majalah dan lain-lain.

2. Data yang terformat adalah data dengan suatu format tertentu, misalnya data yang menyatakan tanggal atau jam, dan nilai mata uang.

3. Citra (image) adalah data dalam bentuk gambar,citra dapat berupa grafik, foto, hasil ronsten, dan tanda tangan.

4. Audio adalah data dalam bentuk suara misalnya, instrumen musik, suara orang, suara binatang, detak jantung, dan lain-lain.

5. Video adalah data dalam bentuk gambar yang bergerak dan dilengkapi dengan suara misalnya, suara kejadian dan aktivitas-aktivitas dalam bentuk film.

\subsubsection{Definisi Informasi}

Menurut (Fatta, 2007), informasi merupakan data yang telah diolah menjadi sebuah bentuk yang berarti bagi penerimanya dan bermanfaat bagi pengambilan keputusan saat ini atau mendatang.

\subsubsection{Kualitas Informasi}

Kualitas informasi sangat dipengaruhi atau ditentuka oleh tiga hal pokok, yaitu akurasi (accuracy), relevansi (relevancy), dan tepat waktu (timeliness) (Sutabri, 2012).

a. Akurasi (accuracy) sebuah informasi harus bebas dari kesalahan dan tidak bias dan menyesatkan. Akurat juga berarti bahwa informasi harus jelas mencerminkan maksudnya. Informasi harus akurat karena dari sumber informasi sampai ke penerima informasi mungkin banyak mengalami ganguan (noise) yang dapat mengubah atau merusak informasi tersebut.

b. Tepat waktu (timeliness) informasi yang disampaikan ada penerima tidak boleh terlambat informasi yang sudah usang tidak akan mempunyai nilai lagi, karena infoormasi merupakan landasan dalam pengambilan keputusan. Bila pengambilan keputusan terlambat akan berakibat fatal bagi organisasi.

c. Relevansi (relevancy) informasi tersebut mempunyai manfaat untuk pemakainya. Relevansi informasi untuk setiap orang, satu dengan yang lainnya adalah berbedah.

\subsubsection{Nilai Informasi}

Parameter untuk mengukur nilai sebuah informasi (value of information) ditentukan dari dua hal pokok yaitu manfaat (benefit) dan biaya (cost), namun dalam kenyataannya informasi yang biaya untuk mendapatkannya tinggi belum tentu memiliki manfaat yang tinggi pula. Suatu informasi dikatakan bernilai bila manfaatna lebih efektif dibandingkan dengan biaya utuk mendapatkannya dan sebagian besar informaasi tidak dapat tepat ditaksir keuntungannya dengan satuan nilai uang, tetapi dapat ditaksir nilai keefektivitasnya (Sutabri, 2012). Nilai informasi ini didasarkan atas 10 (sepuluh) sifat,yaitu :

1. Mudah diperoleh

Sifat ini menunjukkan kemudahan dan kecepatan untuk memperoleh informasi.

2. Luas dan lengkap

Sifat ini menunjukkan kelengkapan isi informasi. Hal ini tidak hanya mengenai volumenya, akan tetapi juga mengenai keluaran informasinya.

3. Ketelitian

Sifat ini berhubungan dengan tingkat kebebasan dan kesalahan keluaran informasi.

4. Kecocokan

Sifat ini menunjukkan seberapa baik keluaran informasi dalam hubungannya dengan permintaan para pemakai.

\section{Ketetapan waktu}


Sifat ini berhubungan dengan waktu yang dilalui, yang lebih pendek dari siklus untuk mendapatkan informasi.

6. Kejelasan

Sifat ini menunjukkan tingkat kejelasan informasi. Informasi hendaknya terbebas dari istilah-istilah yang tidak jelas.

7. Keluwesan

Sifat ini berhubungan dengan apakah informasi tersebut dapat digunakan untuk membuat lebih dari satu keputusan, tetapi juga dapat digunakan untuk lebih dari seorang pengambil keputusan.

8. Dapat dibuktikan

Sifat ini menunjukkan sejauh mana informasi itu dapat diuji oleh beberapa pemakai hingga sampai didapatkan kesimpulan yang sama.

9. Tidak ada prasangka

Sifat ini berhubungan dengan ada tidaknya keinginan untuk mengubah informasi tersebut guna mendapatkan kesimpulan yang telah diarahkan sebelumnya.

10.Dapat diukur

Sifat ini menunjukkan hakikat informasi yang dihasilkan oleh sistem informasi formal.

\subsubsection{Definisi Sistem Informasi}

Sistem informasi adalah suatu sistem di dalam suatu organisasi yang mempertemukan kebutuhan pengolahan transaksi harian, mendukung operasi, bersifat manajerial dan kegiatan strategi dari suatu organisasi dan menyediakan pihak luar tertentu dengan laporan-laporan yang diperlukan (Jogiyanto, 2005).

\subsubsection{Unified Modeling Language}

Untuk mendapatkan banyak pandangan terhadap sistem informasi yang akan dibangun, UML (Unified Modeling Language) menyediakan beberapa diagram visual yang menunjukkan berbagai aspek dalam sistem. Banyaknya diagram tersebut dimaksudkan untuk memberi gambaran yang lebih terintegrasi terhadap sistem yang akan dibangun (Sholiq, 2010).

\subsection{Metode Pengumpulan Data}

a. Metode Observasi

Pengamatan langsung terhadap sistem pemesanan gedung yang ada di kota Palembang untuk memperoleh informasi yang digunakan dan diolah dalam membangun suatu sistem informasi reservasi gedung secara online berbasis android.

b. Metode Wawancara

Wawancara untuk mencari dan mengumpulkan data dengan cara langsung berbicara dengan pemilik gedung graha trisila.

Kemudian narasumber selanjutnya yaitu penyewa yang pernah atau yang ingin bertransaksi di gedung graha trisila. Data yang didapat dari penyewa berguna untuk sistem yang akan dibuat sebagai data pendukung antara lain bagaimana agar penyewa mudah mengakses informasi gedung serbaguna, fasilitas-fasilitas yang tersedia yang dapat dipilih secara fleksibel atau tidak oleh penyewa, kapasitas, dan tambahan fitur lainnya yang di dapat dari hasil wawancara.

c. Metode Dokumentasi

Pengumpulan data yang dilakukan dengan mengamati proses pemesanan tempat yang sedang berjalan di gedung graha trisila. Dokumen yang diperlukan antara lain struktur transaksi yang sedang berjalan agar dapat mengetahui dan membandingkan dengan struktur transaksi pemesanan online yang akan dibangun. 


\subsection{Metode Pengembangan Sistem}

Adapun teknik yang digunakan untuk pembangunan sistem adalah model Prototype yakni metode pengembangan prototype merupakan model proses yang memungkinkan adanya interaksi antara pengembang sistem dengan pengguna sistem, sehingga dapat mengatasi ketidak serasian antara pengembang dan pengguna (Pressman, 2012).

\subsection{Sistem yang sedang berjalan}

Berdasarkan wawancara langsung dengan pemilik gedung serbaguna Graha Trisila Palembang ataupun perwakilan yang dijadikan sampel maka dapat ditarik kesimpulan sebagai Berikut proses untuk pemesanan secara umum:

1. Penyewa menghubungi pihak gedung untuk menanyakan ketersediaan gedung

2. Kemudian pemilik gedung mengecek jadwal gedung, Apabila gedung tersebut tersedia selanjutnya penyewa melihat fasilitas yang ada didalam gedung

3. Apabila setuju selanjutnya penyewa memilih paket dari fasilitas untuk acara yang diselenggarakan seperti catering, entertainment dan lain sebagainya.

4. Jika telah terjadi kesepakatan antara pihak penyewa dan pemilik gedung maka sebagai tanda jadi pemesanan penyewa bisa langsung membayar lunas atau memberikan uang muka sebesar $10 \%$ dari harga keseluruhan dengan ketentuan satu bulan sebelum acara sudah melunasi pembayaran.

5. Kemudian pemilik gedung mencatat jadwal, dan mencatat seluruh fasilitas yang diinginkan penyewa. Dan juga mencetak struk pembayaran untuk penyewa. Sebagai bukti pembayaran uang muka ataupun pembayaran lunas.

6. Apabila penyewa melakukan Proses pembatalan maka uang yang dikembalikan hanya $80 \%$.

\section{HASIL DAN PEMBAHASAN}

Mendeskripsikan layanan, fitur, atau fungsi yang disediakan oleh sistem untuk pengguna, berikut Tabel 1 mendeskripsikan kebutuhan fungsional:

Tabel 1. Kebutuhan Fungsional

\begin{tabular}{cl}
\hline \multicolumn{1}{c}{ Kebutuhan Fungsional } & \multicolumn{1}{c}{ Responsibilities } \\
\hline Proses pemesanan jadwal gedung & $\begin{array}{l}\text { Sistem yang akan dibangun mampu } \\
\text { melakukan proses pemesanan secara } \\
\text { online dengan melihat jadwal yang } \\
\text { kosong } \\
\text { dapat menampilkan paket yang sering } \\
\text { di pesan penyewa berdasarkan acara } \\
\text { Proses pemesanan paket gedung } \\
\text { yang diselenggarakan. } \\
\text { menampilkan fasilitas berupa paket- } \\
\text { paket fasilitas gedung untuk penyewa } \\
\text { gedung }\end{array}$ \\
\hline
\end{tabular}

\subsection{Pemodelan Data}

Setelah melakukan tahapan perencanaan, tahap selanjutnya adalah tahapan permodelan. Adapun permodelan yang dipakai adalah unified modeling language (UML) dikarenakan menggunakan bahasa pemprograman yang digunakan object oriented programming $(O O P)$. Tahapan pemodelan atau desain sistem yang dibangun dibagi menjadi 4 bagian antara lain, Use case diagram, Activity diagram, dan Squence diagram dan Class diagram perancangan 
antarmuka (interface) pengguna sistem yang dibangun, serta perancangan database, yang nantinya diperlukan dalam pembuatan suatu sistem, berikut usulan sistem yang akan dibuat

3.1.1 Usecase Diagram

Perancangan pemodelan usecase diagram menggunakan unified modeling language (UML) dapat dilihat pada Gambar 1 sebagai berikut:

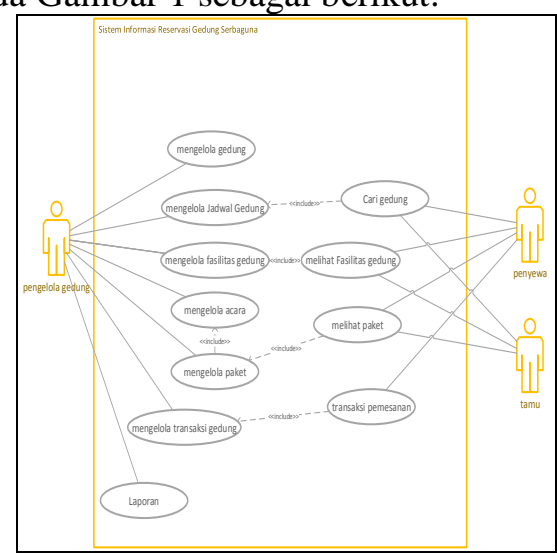

\section{Gambar 1. Usecase Diagram Sustem Informasi Reservasi Gedung}

\subsubsection{Activity Diagram}

Activity diagram adalah diagram yang menggambarkan aliran kerja atau aktivitas dari Sistem reservasi gedung.

a. Activity Diagram Kelola Pemilik Gedung

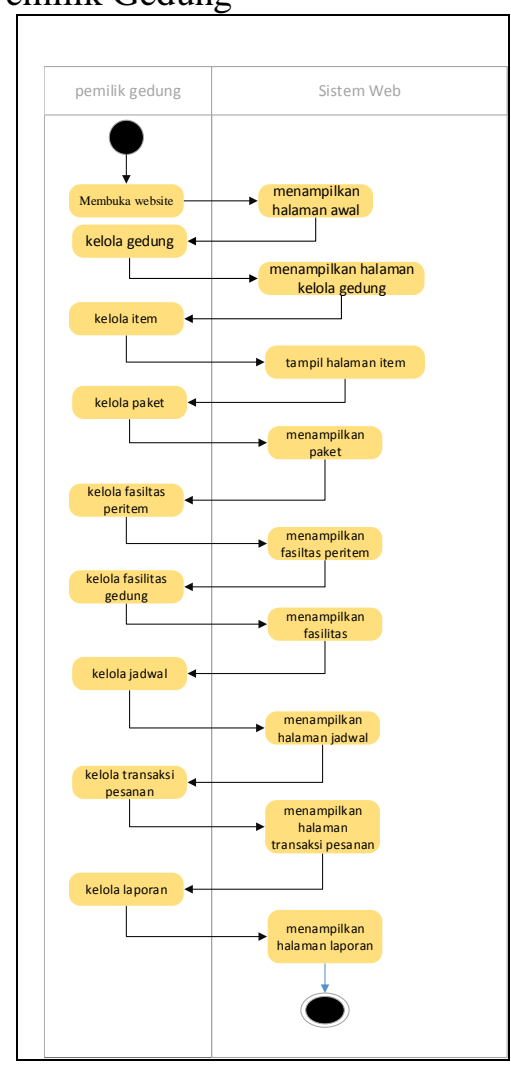

Gambar 2. Activity Diagram Kelola Pemilik Gedung

b. Activity Diagram penyewa 


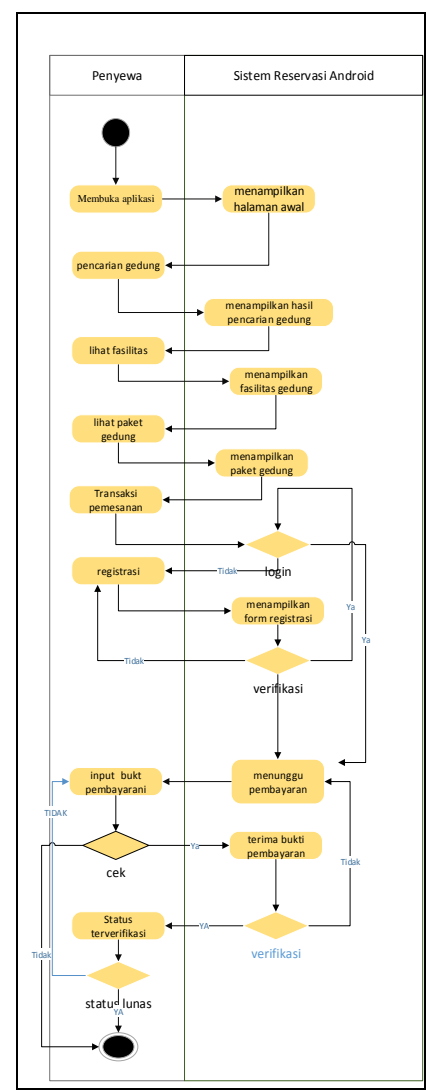

Gambar 3. Activity Diagram penyewa

\subsubsection{Class Diagram}

Class diagram memaparkan mengenai instansiasi objek dari class-class yang ada.

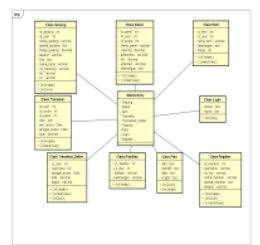

\section{Gambar 4. Class Diagram Reservasi Gedung Serbaguna}

Class diagram diatas yang menggambarkan struktur dan penjelasan class, paket, dan objek serta hubungan satu sama lain seperti containment, pewarisan, asosiasi, dan lain-lain. Class diagram juga menjelaskan hubungan antar class dalam sebuah sistem yang sedang dibuat dan bagaimana caranya agar dapat saling berkolaborasi untuk mencapai sebuah tujuan. Class merepresentasikan sesuatu yang ditangani oleh sistem. 


\subsubsection{Implementasi Interface}

a. Tampilan Halaman Utama

Tampilan front-end (tampilan depan) dari sistem informasi reservasi antara lain halaman utama, halaman fasilitas, dan halaman paket.

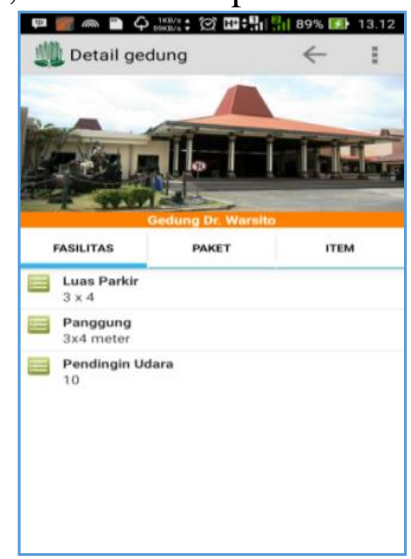

\section{Gambar 5. Tampilan Halaman utama android}

Pada halaman ini merupakan rancangan halaman utama untuk penyewa dan tamu berbasis android yang akan menampilkan rekomendasi paket dan form pencarian jadwal gedung berdasarkan inputan tanggal acara yang ditentukan dari penyewa.

\section{b. Tampilan Paket Gedung}

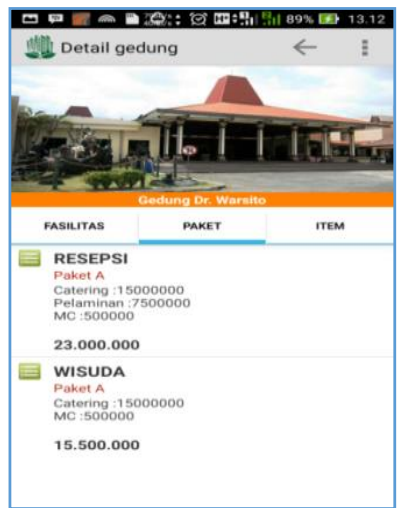

\section{Gambar 6. Tampilan Paket Gedung}

Pada halaman ini merupakan rancangan halaman paket yang akan menampilkan paket yang akan dipilih penyewa

\section{KESIMPULAN}

Berdasarkan hasil penelitian yang telah dilakukan maka dapat diambil kesimpulan yaitu:

1. Sistem informasi reservasi gedung serbaguna menggunakan permodelan UML. Pada bagian front-end berbasis Android sedangkan pada bagian back-end berbasis web.

2. Penyewa dapat menampilkan jadwal kosong berdasarkan tanggal sehingga penyewa dapat menetukan pemesanan gedung serbaguna tanpa harus mendatangi gedung-gedung untuk mendapatkan informasi jadwal gedung

3. Sistem yang dibangun dapat mendata transaksi pemesanan gedung yang masuk dan dengan adanya laporan setiap transaksi pemesanan berupa grafik pada bagian admin . 
102 | JUSIFO (Jurnal Sistem Informasi), p-ISSN: 2460-092X, e-ISSN: 2623-1662

4. Untuk proses pemesanan gedung penyewa dapat memilih fasilitas tambahan secara fleksibel dengan memilih item-item tambahan yang dinginkan penyewa.

\section{DAFTAR PUSTAKA}

Fatta, H. A. (2007). Analisis \& Perancangan Sistem Informasi. Yogyakarta: Andi.

Jogiyanto. (2005). Analisis Dan Desain Sistem Informasi. Yogyakarta: Andi.

Kristanto, A. (2008). Perancangan Sistem Informasi dan Aplikasinya. Yogyakarta: Gava Media.

Pressman, R. (2012). Rekayasa Perangkat Lunak (Pendekatan Praktisi) Edisi 7. Yogyakarta: Andi.

Sholiq. (2010). Analisis dan Perancangan Berorientasi Objek. Bandung: CV. Muara Indah.

Sutabri, T. (2012). Konsep Sistem Informasi. Yogyakarta: Andi.

Yakub. (2012). Pengantar Sistem Informasi. Yogyakarta: Graha Ilmu. 